line of character interest in Beckett's drama. It is also the first of his plays to break completely with scenic realism. For all these reasons, Happy Days is paired with Waiting for Godot as a play of comparable substance and significance.

\title{
2 ENGLish ANd French Versions
}

Beckett is unique in his practice of writing both in English and French and in translating all his works himself from one language to the other. With the translation thus guaranteed by the author, the plays can fairly be studied as selfcontained works in either language. However, acquaintance with the other language text is obviously desirable and can be important.

The plays discussed in the volume fall rather neatly into Beckettian pairs. Waiting for Godot was written in French as En attendant Godot. At the time he wrote it (between October 1948 and January 1949) Beckett had been living in Paris for years and was engaged on a massive trilogy of novels, all written in French. He turned from the second of these, Malone meurt (published like the first, Molloy, in 1951) to write En attendant Godot. (The third novel, L'innomable, was published in 1953.) It was thus natural for the first play he had performed to be in French. Happy Days, on the other hand, like almost all his plays after Fin de partie (Endgame), was written first in English and then translated by Beckett into French as Oh les beaux jours. His respect for Billie Whitelaw's special ability to interpret such arduous roles as Mouth must have been one element in this bias towards the use of English in the theatre. But the bilingualism is always in the background. 